Materiales de Construcción

Vol. 67, Issue 326, April-June 2017, e115

ISSN-L: 0465-2746

http://dx.doi.org/10.3989/mc.2017.00316

\title{
Use of rubber shreds to enhance attenuation of railway sub-ballast layers made of unbound aggregates
}

\author{
C. Hidalgo-Signes ${ }^{\mathrm{a}} \bowtie$, J. Garzón-Roca ${ }^{\mathrm{a}}$, J.M. Grima-Palop ${ }^{\mathrm{b}}$, R. Insa-Franco ${ }^{\mathrm{c}}$ \\ a. Department of Geotechnical and Geological Engineering, Universitat Politècnica de València, (Valencia, Spain) \\ b. Department of Electronic Engineering, Universitat Politècnica de València (Valencia, Spain) \\ c. Department of Transport Engineering and Infrastructure, Universitat Politècnica de València, (Valencia, Spain) \\ $\triangle$ chidalgo@trr.upv.es
}

\begin{abstract}
One of the approaches for solving the problem of induced vibrations in railways is by slightly modifying the materials that form the track. A study is presented of the attenuation capacity of mixes composed of granular soil and rubber shreds when used as sub-ballast (the layer located immediately below the ballast layer). Rubber shreds are obtained from scrap tyres, a troublesome waste material whose reuse and recycling is necessary. A series of mixes of granular soil and rubber shreds with rubber contents of between $1 \%$ and $10 \%$ are submitted to hammer impact tests to study their response to dynamic excitation. Results reveal that mixing rubber shreds with granular soil increases damping ratios, thus demonstrating the potential of the proposed mixes for attenuating vibration.
\end{abstract}

KEYWORDS: Waste treatment; Aggregate; Mixture proportion; Vibration; Acceleration

Citation/Citar como: Hidalgo-Signes, C.; Garzón-Roca, J.; Grima-Palop, J.M.; Insa-Franco, R. (2017) Use of rubber shreds to enhance attenuation of railway sub-ballast layers made of unbound aggregates. Mater. Construcc. 67 [326], e115. http://dx.doi.org/10.3989/mc.2017.00316

RESUMEN: Uso de partículas de caucho para mejorar la capacidad de atenuación de capas granulares de subbalasto en ferrocarriles. Una de las posibles formas de resolver el problema de las vibraciones inducidas por el ferrocarril es llevando a cabo una ligera modificación de los materiales que forman la vía. En este artículo, se presenta un estudio de la capacidad de atenuación de mezclas compuestas por zahorras y partículas de caucho para ser usadas como sub-balasto (capa localizada bajo el balasto). Las partículas de caucho se obtienen a partir de neumáticos fuera de uso, un material problemático cuya reutilización y reciclaje es cada vez más necesario. Las mezclas de zahorra-caucho, con un contenido entre el $1 \%$ y $10 \%$, se someten a una serie de ensayos dinámicos mediante impacto con martillo, estudiando su respuesta frente a la excitación dinámica. Los resultados revelan que la mezcla de partículas de caucho con zahorras aumenta el coeficiente de amortiguamiento, lo que muestra el potencial que poseen las mezclas propuestas para la atenuación de vibraciones.

PALABRAS CLAVE: Tratamiento de residuos; Árido; Proporción de mezcla; Vibración; Aceleración

ORCID ID: C. Hidalgo-Signes (http://orcid.org/0000-0001-6354-4994); J. Garzon-Roca (http://orcid.org/0000-0003-45127067); J.M. Grima-Palop (http://orcid.org/0000-0003-1752-9499); R. Insa-Franco (http://orcid.org/0000-0002-6655-4458)

Copyright: (C) 2017 CSIC. This is an open-access article distributed under the terms of the Creative Commons Attribution License (CC BY) Spain 3.0.

\section{INTRODUCTION}

Vibrations induced by trains are one of the main concerns addressed in the development of railways, especially when lines run through urban areas (1-7).
Various methods such as elastic mattresses (8-10), open and filled trenches (11-13), and improved fastening systems (14) have been proposed to mitigate vibrations. Alternatively, a more integrated solution consists of introducing a slight modification 
in the materials that form the track to improve performance. One of these options includes the use of rubber obtained from scrap tyres.

Scrap tyres are a troublesome waste material, produced in large quantities and whose disposal is problematic (15-17). Taking into account that scrap tyres need nearly 600 years to completely decompose (18), it is evident that management of this material is one of the current challenges of our society. A suitable reuse and recycling of scrap tyres is therefore a promising way of solving the problem. Scrap tyres can be easily recycled in the form of rubber shreds, obtaining a material that absorbs dynamic effects thanks to its mechanical properties. This paper proposes the use of rubber shreds mixed with unbound granular materials to reduce vibrations induced by trains. Figure 1 shows a typical cross-section of a railway track. Sub-ballast layers are suitable for absorbing train vibrations because of their location between the ballast and the blanket layer. These layers are mostly comprised of granular soil materials, which do not generally absorb vibrations well. However, the addition of a small portion of rubber shreds is expected to enhance the dynamic performance, resulting in a new material that is promising in building and environmental terms.

Rubber has been shown to successfully absorb train vibrations when added to bituminous and concrete mixes (19-21), and when used directly to form an intermediate layer between ballast and subballast (22). Nevertheless, research regarding the addition of rubber to an unbound granular material is still limited. Feng and Sutter (23) studied variation in the shear modulus and the damping coefficient of rubber-sand mixes using a resonant column test, but did not reach any significant result. Nakhaei et al. (24) performed triaxial tests for different mixes of soil and rubber and found that higher rubber contents led to decreases in the damping coefficient of

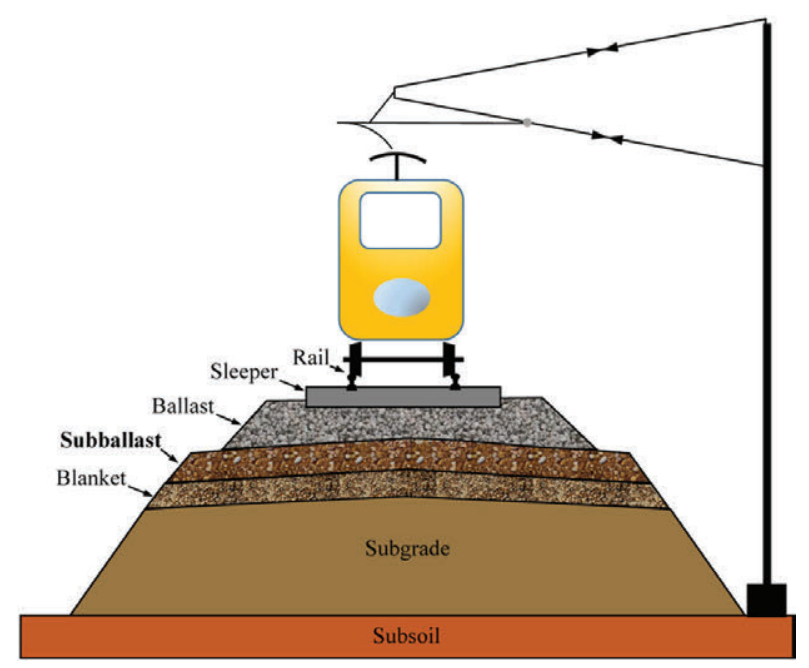

FIGURE 1. Typical cross-section of a railway track. the mix when tested under pressures of between 50 and $100 \mathrm{kPa}$, but produced the opposite effect when tested under pressures of between 200 and $300 \mathrm{kPa}$. Hidalgo et al. (25) carried out laboratory and field tests and concluded that mixes with a rubber content of between $1 \%$ and $5 \%$ by weight resulted in a new material with good mechanical properties (although bearing capacity suffered a slight - but totally acceptable - reduction) with an improved resistance to degradation and improved elastic recovery.

In the present paper, the potential capacity for attenuating railway vibrations using sub-ballast mixes composed of aggregate material and rubber shreds is assessed. Specimens with a rubber content of between $1 \%$ and $10 \%$ by weight are submitted to hammer impact tests to study their response to dynamic excitation. The hammer impact test is used to produce a perfect impulse for an infinitely small duration - thereby causing a constant amplitude in the frequency domain. Evaluation of the sub-ballast mixes is made by means of their damping coefficient values, which are computed (26) in the time domain (logarithmic decrement method) and frequency domain (bandwidth method).

\section{MATERIALS AND METHODS}

\subsection{Materials}

Unbound granular materials used in this study were dolomitic in nature and extracted from a quarry near the town of Villena (Spain) which is located approximately $120 \mathrm{~km}$ from the laboratory facilities. Several tests were conducted on these materials, including granulometric, density, and water absorption (see Table 1). Figure 2 depicts their corresponding granulometric curves. Based on this data, the material collected was found to comply with the general characteristics of a sub-ballast material (27-30).

Rubber shreds were obtained from scrap tyres and supplied by the Spanish recycling company $\mathrm{RMD}^{\circledR}$. For configuring the sub-ballast mixes, the rubber particles were sized between 8 and $18 \mathrm{~mm}$ with a low percentage of fibres. Steel wires (always presented in rubber tyres) were removed to avoid the introduction of any metallic element in the tested mixes. Similar to the unbound granular materials, tests such as granulometric, density, and water absorption were undertaken on the rubber shreds to fully characterise this component (see Table 1).

\subsection{Specimens characteristics}

The tested specimens consisted of compacted samples of granular materials and mixes of granular materials with rubber shreds placed in transparent and hollow PVC tubes with an external diameter of 110 $\mathrm{mm}$, a thickness of $2.2 \mathrm{~mm}$, and a length of $1120 \mathrm{~mm}$. 
TABLE 1. Material characterisation

\begin{tabular}{|c|c|c|c|c|}
\hline Parameter & Standard & Unit & Unbound granular material & Rubber shreds \\
\hline Uniformity coefficient $(\mathrm{Cu})$ & $\begin{array}{l}\text { ASTM D6913 (34) } \\
\text { UNE-EN 933-1:1998 (35) }\end{array}$ & - & 80 & 1.4 \\
\hline Coefficient of curvature $(\mathrm{Cc})$ & $\begin{array}{l}\text { ASTM D6913 (34) } \\
\text { UNE-EN 933-1:1998 (35) }\end{array}$ & - & 1.4 & 0.9 \\
\hline Coefficient of permeability (K) & $\begin{array}{l}\text { ASTM D7760 (36) } \\
\text { PF-7 (30) }\end{array}$ & $\mathrm{m} / \mathrm{s}$ & $3.05 \cdot 10^{-7}$ & $2.1 \cdot 10^{-5}$ \\
\hline Dry density & $\begin{array}{l}\text { ASTM C127 (37) } \\
\text { UNE-EN 1097-3:1999 (38) }\end{array}$ & $\mathrm{g} / \mathrm{cm}^{3}$ & 2.77 & 1.14 \\
\hline Water absorption & $\begin{array}{l}\text { ASTM C127 (37) } \\
\text { UNE-EN 1097-3:1999 (38) }\end{array}$ & $\%$ & 0.71 & 5.00 \\
\hline Max dry density & $\begin{array}{l}\text { ASTM D1557 (31) } \\
\text { UNE 103501:1994 (32) }\end{array}$ & $\mathrm{g} / \mathrm{cm}^{3}$ & 2.36 & 0.57 \\
\hline Optimal moisture & $\begin{array}{l}\text { ASTM D1557 (31) } \\
\text { UNE 103501:1994 (32) }\end{array}$ & $\%$ & 6.2 & - \\
\hline Atterberg limits & $\begin{array}{l}\text { ASTM D4318 (39) } \\
\text { UNE103103:1994 (40) } \\
\text { UNE103104:1993 (41) }\end{array}$ & - & No plasticity & - \\
\hline Los Angeles (LA) & $\begin{array}{l}\text { ASTM C131 (42) } \\
\text { UNE-EN 1097-2:1999 (43) }\end{array}$ & - & 25 & - \\
\hline Micro-Deval (MDH) & $\begin{array}{l}\text { ASTM D6928 (44) } \\
\text { UNE-EN 1097-1:1997 (45) }\end{array}$ & - & 10.5 & - \\
\hline Organic matter content & $\begin{array}{l}\text { ASTM D2974 (46) } \\
\text { UNE 103204:1993 (47) }\end{array}$ & $\%$ & 0.09 & - \\
\hline
\end{tabular}

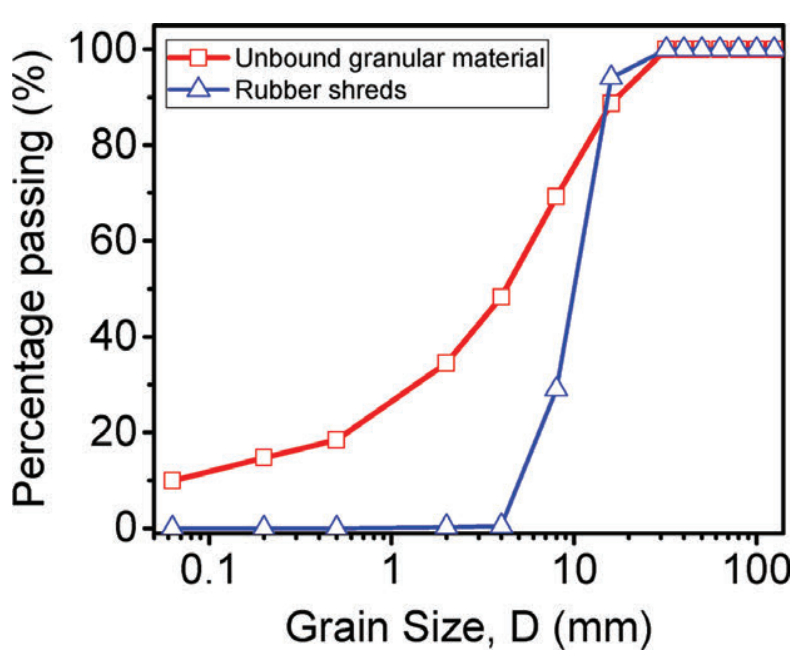

FIGURE 2. Granulometric curve of the unbound granular soil and the rubber shreds.

Four quantities of rubber shreds introduced in the granular soil were studied: $1 \%, 2.5 \%, 5 \%$ and $10 \%$ over the granular soil weight. Selected dimensions of the specimens took into account various factors, including: heterogeneity of the samples; size of granular soil particles (tube diameter was set at more than five times the maximum soil size); workability conditions; and the need to ensure sufficient slenderness to facilitate the flexural behaviour of the specimens so as to obtain representative values of vibration damping. According to the material supplier, the PVC tubes had a density of $1.36 \mathrm{~g} / \mathrm{cm}^{3}$ and water absorption of $0.5 \%$, with an elastic modulus of $3040 \mathrm{MPa}$. These characteristics ensured that the tubes selected did not have a significant influence on the dynamic response of specimens, and were sufficiently stiff and strong to hold the compacted sample.

Unbound granular materials obtained from the quarry were firstly dried to remove any residual water content. Since each specimen needed more than $20 \mathrm{~kg}$ of sample material, homogeneity was achieved by creating 15 subsamples. In each subsample, the granular material was mixed with rubber shreds, and thereafter, the optimum water content for compaction was added. Each subsample was independently and adequately stored in the laboratory. Before compaction, the moisture and dry density of every sample was measured, and a standard Proctor modified test was also performed $(31,32)$.

Compaction of the samples in the PVC tube was conducted by using a vibrating compaction hammer (Kango 900 model) equipped with a tamping foot (100 $\mathrm{mm}$ in diameter) capable of exercising an energy blow of $16.4 \mathrm{~J}$ with a frequency of about $33 \mathrm{~Hz}$. The total weight of this equipment was nearly $35 \mathrm{~kg}$. Although the thickness of the PVC tube was expected to be able to bear the compaction stresses, nylon clamps were fitted to the tube during compaction of the samples to improve mechanical performance during this process. The compaction operation was carried out in 15 layers 
with a rate of $10 \mathrm{~s}$ of vibration per layer. This procedure, which was determined after carrying out a series of preliminary trial and error tests, ensured that nearly $100 \%$ of the dry density of the sample was reached.

Once compaction was finished, the tube ends were closed using polyurethane plates and adhesive tape to avoid any loss of material during the manipulation and testing of the specimens. Specimens were stored in a climatic chamber with a constant temperature and relative humidity of $20^{\circ} \mathrm{C}$ and $95 \%$ respectively. The specimen preparation process is summarised in Figure 3.
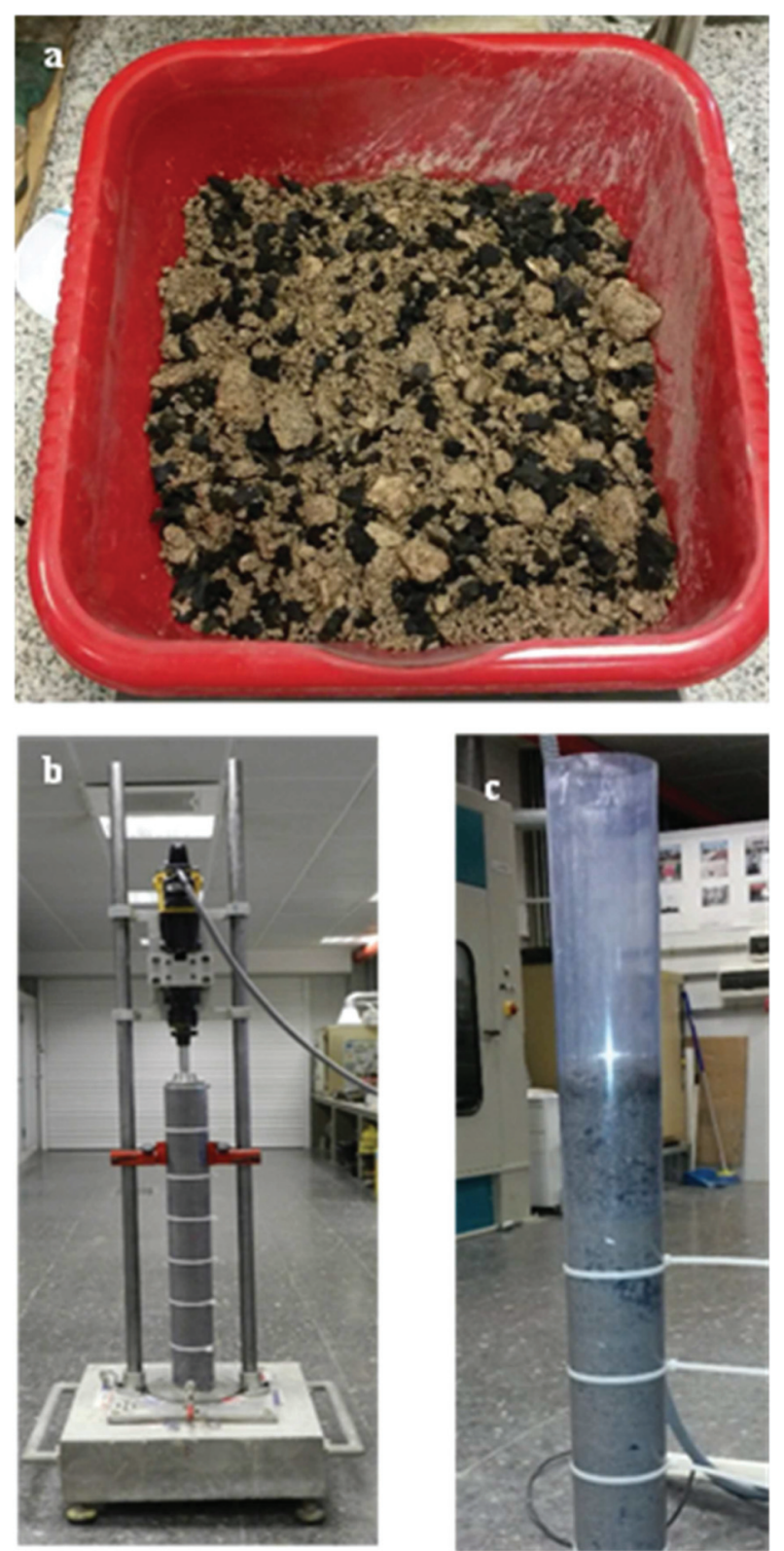

FIgURE 3. Specimen preparation: (a) sample mixing; (b) vibrating compaction hammer used for samples compaction; (c) PVC tube filling.
As indicated in Table 2, specimens were named $S U B \_X$, with $X$ equal to $R E F$ for the reference case, i.e. traditional soil-only sub-ballast (no rubber shred), and equal to MIXp when testing the proposed mix of granular soil and rubber shreds, being $p$ the percentage of rubber introduced over the granular soil weight. Average values for dry density and moisture in each of the tested specimens are also referred to in Table 2. It can be seen that maximum dry density significantly decreases with the amount of rubber introduced in the soil. Similarly, a slight decrease in the optimum moisture is observed. The reduction found in dry density and optimum moisture is approximately proportional to the rubber shred content.

\subsection{Test method}

To study the capacity of the proposed mixes to attenuate vibrations, specimens were submitted to a hammer impact test according to (33). Tests were carried out in the Geotechnical Laboratory of the Universitat Politècnica de València.

Specimens were placed horizontally and subjected to two structural configurations as depicted in Figures 4 and 5: (i) simply supported on steel rollers (referred hereafter as the ' $\mathrm{S}$ ' configuration); and (ii) uniformly supported on highly damping polyurethane (PU) foam (referred hereafter as the ' $U$ ' configuration).

The excitation impact was applied at a distance of $50 \mathrm{~mm}$ from one of the ends of the specimen by an impulse hammer with a force sensor and tips (0-100 lbf, PCB 086C01 model). A piezoelectric accelerometer (MEF KS76C100) with a sensitivity of $100 \mathrm{mV} / \mathrm{g}$, a frequency range of between $0.13 \mathrm{~Hz}$ to $24 \mathrm{kHz}$, and an acceleration range of up to $6 \mathrm{~g}$, was used for registering the vibrations induced by the hammer. A sampling frequency of $200 \mathrm{~Hz}$ was selected, and a signal conditioner (MEF M32 model) with an IEPE exit signal, was used to improve the signal received by the data acquisition system. For each structural configuration mentioned (S and U), two tests were conducted by alternatively placing the accelerometer in two positions (see Figures 4 and 5): (1) at the mid-span section; and (2) at a distance of $50 \mathrm{~mm}$ from the opposite end to where the impact was applied. A flow chart of the specimen preparation and testing can be seen in Figure 6.

\section{RESULTS AND DISCUSSION}

\subsection{Hammer impact test results}

A series of hammer impact tests were carried out on the compacted samples of granular soil and mixes of granular soil with rubber shred specimens. The values of the vibration amplitudes induced in the specimens by the hammer and its consequent 
TABLE 2. Specimens tested

\begin{tabular}{|c|c|c|c|c|}
\hline Series & Rubber shreds content ( $\%$ in weight) & Dry density $\left(\mathrm{g} / \mathrm{cm}^{3}\right)$ & Compaction (\%) & Moisture (\%) \\
\hline SUB_REF & 0.0 & 2.36 & 100.0 & 6.1 \\
\hline SUB_MIX1 & 1.0 & 2.30 & 100.0 & 6.2 \\
\hline SUB_MIX2.5 & 2.5 & 2.21 & 97.8 & 6.1 \\
\hline SUB_MIX5 & 5.0 & 2.11 & 97.7 & 6.0 \\
\hline SUB_MIX10 & 10.0 & 2.01 & 98.0 & 6.0 \\
\hline
\end{tabular}

(a)

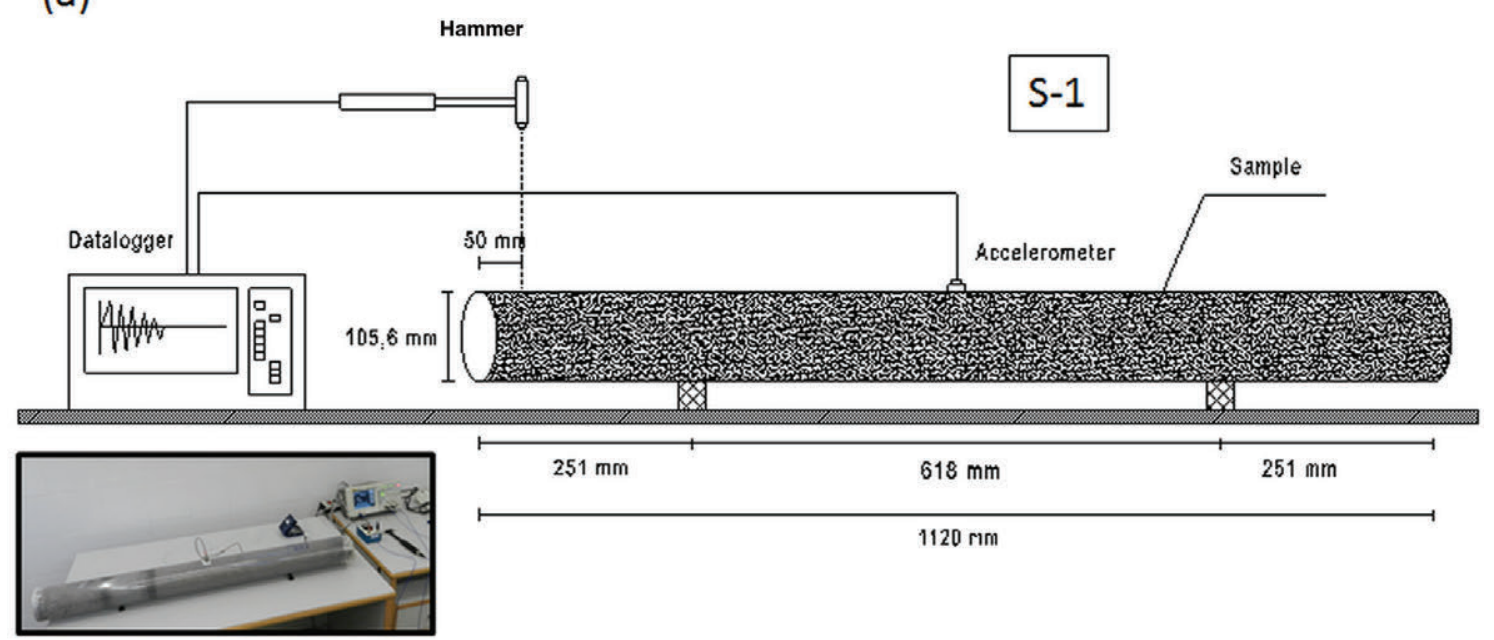

(b)

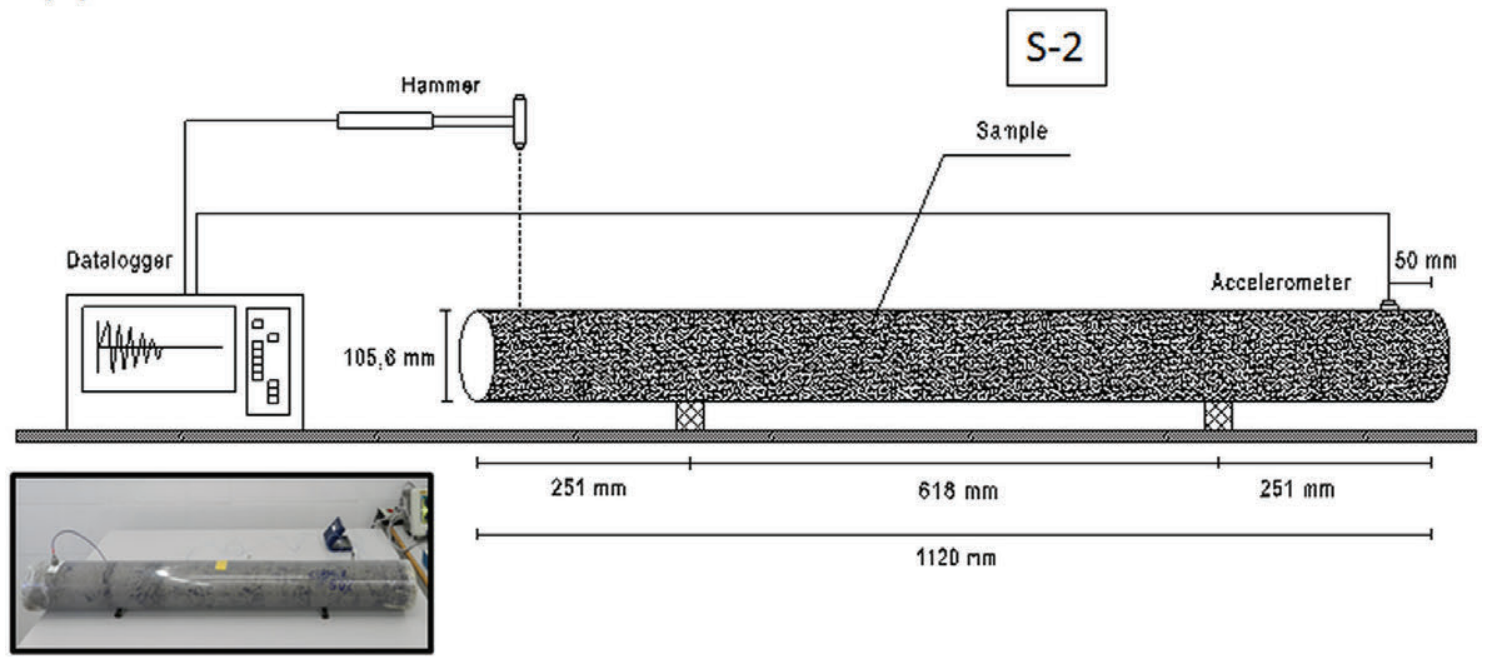

FIGURE 4. Impact hammer test setups with a simply supported ('S') configuration: (a) with the accelerometer placed at mid-span; (b) with the accelerometer placed at opposite end to where impact is applied.

and progressive diminution over time were registered. Figure 7 shows the registered excitation over time, as well as the correspondent spectra for specimens SUB_REF, SUB_MIX2.5 and SUB_MIX10 under the ' $S$ ' structural configuration (simply supported) and for the accelerometer placed at the opposite end to where the impact is applied with the hammer (configuration 2).

As can be seen, in the time domain there are no significant differences between these three tests at first sight and the specimens with and without rubber shreds behave similarly. Conversely, the three 
(a)

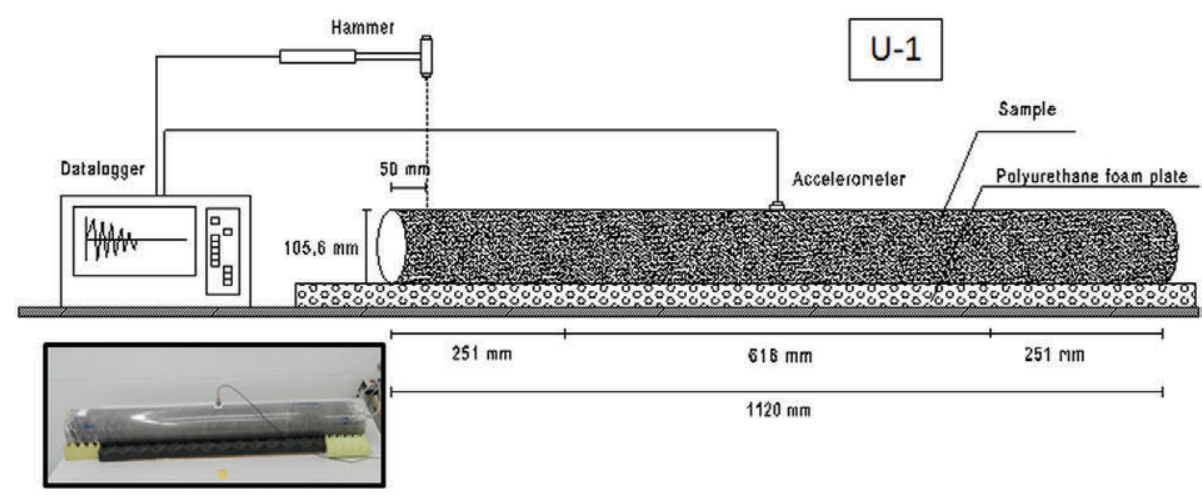

(b)

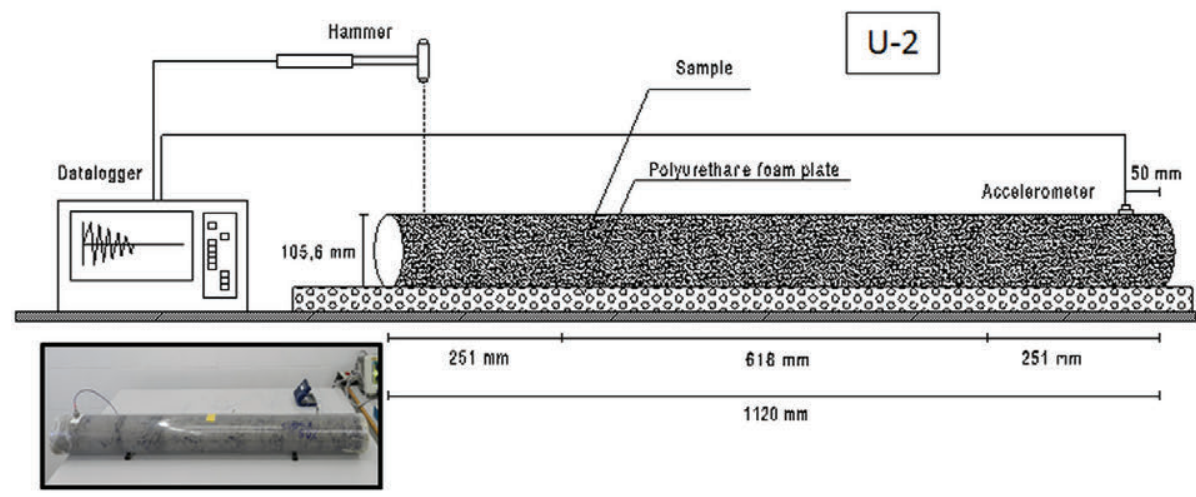

FIGURE 5. Impact hammer test setups with a uniform support ('U') configuration: (a) with the accelerometer placed at mid-span; (b) with the accelerometer placed at the opposite end to where impact is applied.

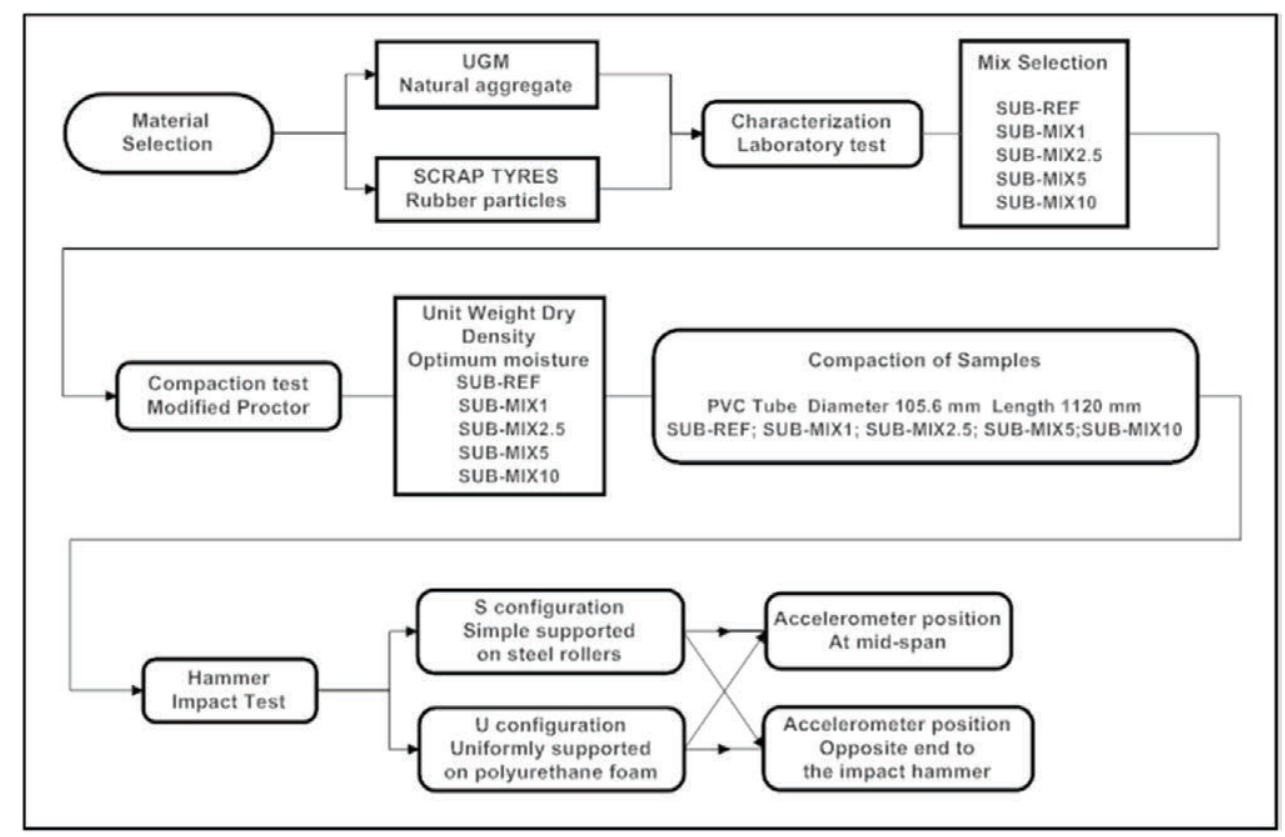

FIGURE 6. Specimen preparation and testing flow chart. 

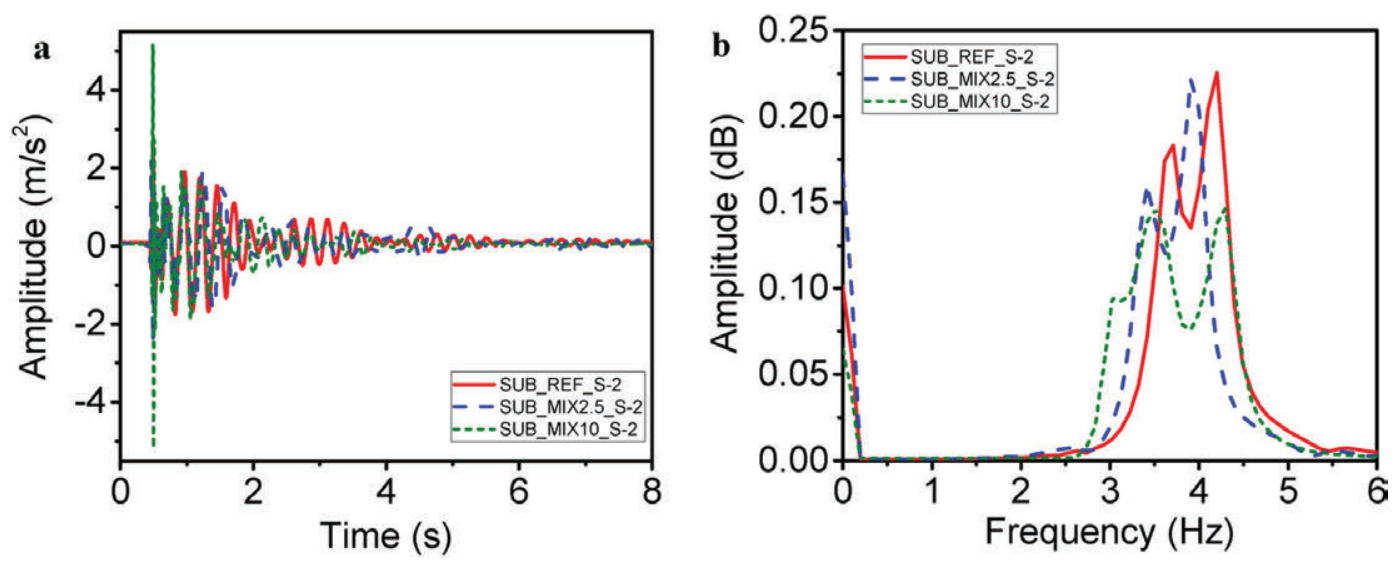

FIGURE 7. Hammer impact test results for specimens SUB_REF_S-2, SUB_MIX2.5_S-2 and SUB_MIX10_S-2: (a) excitation registered in time domain; (b) spectral representation (frequency domain).

spectra show a similar pattern in the frequency domain, but the spectra for specimens with rubber shreds is slightly shifted to lower frequencies, which means they have a lower natural frequency.

It was assumed that the natural frequency of the specimens relates to the first of the peaks. The presence of the second peak, very close to the first, might be put down to the existence of some spurious modes which are present in the studied signal due to different sources of noise. It should be noted that the specimens tested are very heterogeneous, since no cementitious material is present, and are composed of granular soil, shredded rubber, water, and the PVC tube. Besides, a hammer impact test introduces a punctual and sudden excitation in the samples. Even though these aspects may have interfered in the registered signals, such events are normal in dynamic testing, and so the results obtained can be considered completely useful.

\subsection{Attenuation}

The potential attenuation that the inclusion of rubber shreds may cause in a compacted granular soil was studied by obtaining the damping ratio, $\zeta$, in each specimen tested. This parameter can be found (26) in both the time domain of the signal and the frequency domain. In the time domain, the damping ratio can be derived from the logarithmic decrement in the signal, i.e. the natural $\log$ of the ratio of the amplitudes of any two successive peaks using Eq. [1]:

$$
\zeta=\frac{1}{\sqrt{1+(2 \pi / \delta)}}
$$

where $\delta$ is the logarithmic decrement, which can be obtained using Eq. [2]:

$$
\delta=\frac{1}{n} \ln \left(\frac{A_{1}}{A_{2}}\right)
$$

being $A_{1}$ and $A_{2}$, two amplitudes (with $A_{1}>A_{2}$ ) separated $n$ successive peaks.

The bandwidth method was used for the frequency domain. On this method, once the spectrum of the given signal is computed, the damping ratio is easily obtained according to Eq. [3]:

$$
\zeta=\frac{\Delta \omega}{2 \omega_{n}}
$$

where $\omega_{n}$ is the natural frequency of the system, and $\Delta \omega$ the distance between the two frequencies located in the same peak as $\omega_{n}$, but for a spectral amplitude value equal to that registered for $\omega_{n}$ and divided by $\sqrt{2}$.

For the case of the specimens study, both aforementioned procedures were applied for computing the value of the damping ratio, $\zeta$. Results are summarised in Table 3, in which in addition to the value of $\zeta$ for each specimen, the values are listed for the maximum amplitude $\left(A_{\max }\right)$ registered during tests, as well as natural frequencies $\left(\omega_{n}\right)$. Moreover, for every series of specimens, average values are also shown.

An analysis of the results reveals that the values obtained for the damping ratio for both approaches differ significantly. In the case of the time domain, the damping value ratios are almost identical in all the tests carried out. This gives rise to the idea that using the logarithmic decrement method in the time domain is not an optimal approach with unbound granular materials, due to the diverse sources of noise that might be present in the signals and which may produce no significance for the results.

However, the values of the damping ratio extracted by using the bandwidth method show that the addition of rubber shreds to the unbound granular materials considerably increases this parameter as expected, and consequently the capacity of the sub-ballast to absorb and attenuate vibrations. Hence, the frequency domain shows to be a suitable 
TABLE 3. Damping ratios

\begin{tabular}{|c|c|c|c|c|}
\hline \multirow[b]{2}{*}{ Series } & \multicolumn{2}{|c|}{ Time domain } & \multicolumn{2}{|c|}{ Frequency domain } \\
\hline & $\begin{array}{c}A_{\max } \\
\left(\mathrm{m} / \mathrm{s}^{2}\right)\end{array}$ & $\zeta(\%)$ & $\omega_{\mathrm{n}}(\mathbf{H z})$ & $\zeta(\%)$ \\
\hline SUB_REF_S-1 & 3.09 & 2.12 & 2.83 & 3.62 \\
\hline SUB_REF_S-2 & 2.44 & 2.13 & 3.71 & 3.77 \\
\hline SUB_REF_U-1 & 5.18 & 1.51 & 1.27 & 2.85 \\
\hline SUB_REF_U-2 & 4.62 & 1.16 & 1.37 & 3.18 \\
\hline SUB_REF & 3.83 & 1.73 & 2.29 & 3.36 \\
\hline SUB_MIX1_S-1 & 3.49 & 2.10 & 1.96 & 9.45 \\
\hline SUB_MIX1_S-2 & 2.20 & 0.93 & 3.22 & 5.64 \\
\hline SUB_MIX1_U-1 & 3.46 & 1.36 & 1.46 & 9.21 \\
\hline SUB_MIX1_U-2 & 3.02 & 2.70 & 1.47 & 6.79 \\
\hline SUB_MIX1 & 3.04 & 1.77 & 2.03 & 7.77 \\
\hline SUB_MIX2.5_S-1 & 1.68 & 1.21 & 2.73 & 4.38 \\
\hline SUB_MIX2.5_S-2 & 3.20 & 0.91 & 3.42 & 5.24 \\
\hline SUB_MIX2.5_U-1 & 2.29 & 1.84 & 1.34 & 9.93 \\
\hline SUB_MIX2.5_U-2 & 3.85 & 2.26 & 1.47 & 7.61 \\
\hline SUB_MIX2.5 & 2.76 & 1.55 & 2.24 & 6.79 \\
\hline SUB_MIX5_S-1 & 2.45 & 1.82 & 3.13 & 3.04 \\
\hline SUB_MIX5_S-2 & 3.12 & 1.28 & 3.71 & 4.07 \\
\hline SUB_MIX5_U-1 & 4.92 & 1.52 & 1.37 & 8.57 \\
\hline SUB_MIX5_U-2 & 4.58 & 1.44 & 1.47 & 7.16 \\
\hline SUB_MIX5 & 3.77 & 1.51 & 2.27 & 5.71 \\
\hline SUB_MIX10_S-1 & 5.18 & 1.60 & 3.03 & 3.40 \\
\hline SUB_MIX10_S-2 & 5.18 & 1.24 & 3.52 & 6.34 \\
\hline SUB_MIX10_U-1 & 5.09 & 1.79 & 1.56 & 7.68 \\
\hline SUB_MIX10_U-2 & 5.18 & 1.10 & 1.66 & 5.99 \\
\hline SUB_MIX10 & 5.16 & 1.43 & 2.44 & 5.85 \\
\hline
\end{tabular}

approach to study this kind of materials; likely, that can be explain because of own the nature of the use of the frequency domain, which makes signals be clearer.

A noticeable dispersion of results in the frequency domain is observed in some specimens though, probably due to the aforementioned noise issues, as well as the own heterogeneity of the tested samples. As Figure 8 depicts, an increment in the damping ratio is more evident when using the ' $U$ ' structural configuration, i.e. when the specimens are laying on PU foam; in these cases, increments of between the $105 \%$ and the $191 \%$ are observed. In contrast, the simply supported structural configuration ('S') gives more scattered values, ranging from increments of around $100 \%$ to cases of very low $(30 \%)$ increments or even no increments. The scattering observed in the 'S' configuration may have been the consequence of the reduced elastic modulus of specimens (i.e. of the mixes of granular materials and rubber shreds), as well as the absence of cohesion in the specimens (it is important to remember that specimens were 'only'

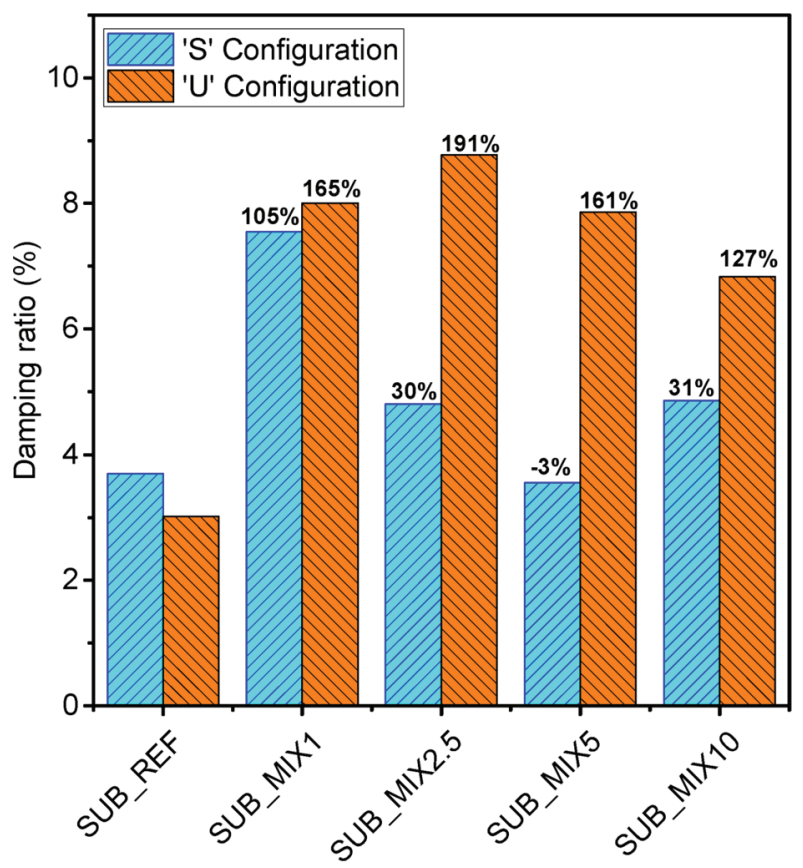

FIGURE 8. Variation in damping ratio. Note: percentages represent the increment in the damping ratio shown by the mix specimen with respect to the reference specimen (for a given structural configuration).

compacted, but any kind of bound material was used). This may have caused a small disturbance in the wave transmission when specimens were excited with the hammer. Given the less scattered results, the use of the uniform PU layer support ('U' configuration) appears to mitigate this aspect.

\subsection{Optimum amount of rubber shred}

As reported in previous research (25), the addition of rubber shreds to granular soil tends to decrease degradation of the materials (a reduction in the values of both Los Angeles and Micro-Deval tests is observed), and this enables the use of unbound granular materials that cannot otherwise fulfil subballast specifications. However, as the rubber content increases, a lower bearing capacity (CBR) is registered. Furthermore, as shown above, the maximum dry density attained by the soil, as well as its optimum water content, are also dependent on the rubber shred content added - and both parameters tend to decrease as rubber content increases.

Conversely, the obtained results show no evidence that a greater amount of rubber shred will cause an increase in the damping ratio. Therefore, at least for the percentages of rubber shreds used in this study (less than $10 \%$ by weight), there is no optimum amount of rubber in terms of attenuation capacity. Instead, the results show that an average increase in the damping ratio of around the $95 \%$ can be expected once rubber is added to a 
granular soil. Hence, the amount of rubber to be added will should be determined based on other issues like those previously related.

\section{CONCLUSIONS}

This paper has assessed the capacity for attenuating railway vibrations with sub-ballast layers that are composed of mixes of unbound granular material and rubber shred from scrap tyres. A reference soil-only specimen and four mixes of granular soil and rubber shred specimens (with rubber contents of $1 \%, 2.5 \%, 5 \%$ and $10 \%$ by weight) were subjected to a series of hammer impact tests. The specimens were tested under two structural configurations: simply supported; and uniformly supported on highly damping PU foam. An accelerometer was alternatively placed at mid-span and at the opposite end to where the hammer struck.

Several characterisation tests, including granulometric, water content, and dry density were conducted on the specimen constituent materials (unbound granular soil and rubber shreds) showing that the proposed mixes fulfil all the requirements to be used as a sub-ballast layer (27-30). Proctor modified tests $(31,32)$ were carried out on the specimens and revealed that both the maximum dry density and the optimum moisture decrease with the amount of rubber shreds introduced in the soil this reduction being approximately proportional to the rubber shred content.

The results of the hammer impact tests show that the addition of rubber slightly shifts the spectra to lower frequencies, leading to lower natural frequencies. The potential capacity of attenuation was analysed by means of the damping ratios. Since some source of noise appeared in the signals, resulting in the impossibility of their study in the time domain, the bandwidth method (frequency domain method) was used to extract and compare the damping ratios. Two types of structural configurations were tested: simply supported; and uniformly supported on PU foam. The analyses performed have shown that less scattered results are obtained when using the uniformly supported configuration since noise issues related to the low elastic modulus of the specimens and the absence of cohesion are mitigated. It is interesting to note that currently there is no standard for determining the natural frequencies of unbound materials. Therefore, according observations in this paper, the optimal approach for studying these materials may be to lay the specimen on a soft support (such as the PU foam used) and compute damping coefficients in the frequency domain.

The results obtained reveal that mixing rubber shreds with granular soil leads to an average increase of $95 \%$ in the damping ratio, thus proving the potential capacity of the proposed mixes for attenuating vibration. However, no evidence of a tendency correlating the amount of rubber introduced in the soil and the reduction experienced by the damping ratio was found. Further research is needed to confirm that though.

\section{ACKNOWLEDGEMENTS}

The authors wish to thank Guerola SA for providing the soil samples from its quarry, RMD for providing the rubber particles, and Ángel Morilla Rubio, Elias Medel Perallón, Pablo Martínez Fernández and Gonçalo Escusa for their help during the laboratory tests.

\section{NOTATION}

The following symbols are used in this paper:

$\mathrm{A}_{\mathrm{i}}=$ Acceleration amplitude.

$\mathrm{A}_{\max }=$ Maximum acceleration amplitude.

$\mathrm{n}=$ Number of successive peaks between the amplitudes $\mathrm{A}_{\mathrm{i}}$.

$\Delta \omega=$ Frequency range between $\pm \omega_{n} / \sqrt{ } 2$

$\delta=$ Logarithmic decrement.

$\zeta=$ Damping ratio.

$\omega_{n}=$ Natural frequency of the system.

\section{REFERENCES}

1. Auersch, L. (2005) The excitation of ground vibration by rail traffic: theory of vehicle-track-soil interaction and measurements on high-speed lines. J. Sound Vib. 284, 103-132. http://dx.doi.org/10.1016/j.jsv.2004.06.017.

2. Di Mino, G.; Di Liberto, M. (2007) Modelling and experimental survey on ground borne vibration induced by rail traffic. 4th International SIIV Congress, Palermo, 2007.

3. Thompson, D.J. (2009) Railway Noise and Vibration: Mechanisms, Modelling and Means of control, Elsevier Ed. Oxford, (2009).

4. Ryue, J.; Thompson, D.J.; White, P.R.; Thompson D.R. (2008) Wave Propagation in Railway Tracks at High Frequencies. Noise and Vibration Mitigation for Rail Transportation Systems, 440-446, Edited by SchulteWerning, B.; Thompson, D.; Gautier, P.E.; Hanson, C.; Hemsworth, B.; Nelson, J; Maeda, T.; de Val, P., Springer Berlin Heidelberg, (2008). http://dx.doi. org/10.1007/978-3-540-74893-9 62 .

5. Zhang, W.; Dai, J.; Sun, B.; Du, Y. (2007) FBG sensor network in Qinghai-Tibet railway monitoring system. SPIE Proceedings Vol. 6830, Advanced Sensor Systems and Applications III, 488-495, Edited by Rao, Y.J.; Liao, Y.; Peng G.D., SPIE International Society for Optic and Photonics, Beijing, (2007).

6. Oertli, J. (2000) Cost-Benefit Analysis in Railway Noise Control. J. Sound Vib. 231 [3], 505-509. http://dx.doi. org/10.1006/jsvi.1999.2539.

7. Kouroussis, G.; Verlinden, O.; Conti, C. (2009) Ground propagation of vibrations from railway vehicles using a finite/infinite-element model of the soil. Proc. Inst. Civ. Eng. Transp. 223 [4], 405-413. http://dx.doi. org/10.1243/09544097JRRT253.

8. Alves Costa, P.; Calçada, R.; Silva Cardoso, A. (2012) Ballast mats for the reduction of railway traffic vibrations. Numerical study. Soil Dyn. Earthquake Eng. 42, 137-150. https://dx.doi.org/10.1016/j.soildyn.2012.06.014.

9. Lombaert, G.; Degrande, G.; Vanhauwere, B.; Vandeborght, B.; François, S. (2006) The control of ground-borne vibrations from railway traffic by means of continuous floating slabs. J. Sound Vib. 297 [3-5], 946-961. http://dx.doi. org/10.1016/j.jsv.2006.05.013. 
10. Zhao, C.; Wang, P.; Yi, Q.; Meng, D. (2015). Viability Analysis of Waste Tires as Material for Rail Vibration and Noise Control in Modern Tram Track Systems. Shock Vib. 2015, Article ID 725808, 12 pages. http://dx.doi. org/10.1155/2015/725808.

11. Alzawi, A.; Hesham El Naggar, M. (2011) Full scale experimental study on vibration scattering using open and in-filled (GeoFoam) wave barriers. Soil Dyn. Earthquake Eng. 31 [3], 306-317. http://dx.doi.org/10.1016/j.soildyn.2010.08.010.

12. Jones, C.J.C.; Thompson D.J.; Andreu Medina, J.I. (2011) Initial theoretical study of reducing surface-propagating vibration from trains using earthworks close to the track. Eighth International Conference on Structural Dynamics EURODYN, Leuven, 2011.

13. Karlström, A.; Boström, A. (2007) Efficiency of trenches along railways for trains moving at sub- or supersonic speeds. Soil Dyn. Earthquake Eng. 27 [7], 625-641. http:// dx.doi.org/10.1016/j.soildyn.2006.12.005.

14. Zhao, C.; Wang, P.; Zhu, Y.; Zhao W.; Xiao J. (2012) Theoretical Analysis and Experimental Study on vibration damping fastening. Journal of Vibration and Shock 31 [23], 191-196.

15. Sharma, V.K.; Fortuna, F.; Mincarini, M.; Berillo, M.; Cornacchia, G. (2000) Disposal of waste tyres for energy recovery and safe environment. Appl. Energy. 65 [1-4], 381-394. https://doi.org/10.1016/S0306-2619(99)00085-9.

16. Sheehan, P.J.; Warmerdam, J.M.; Ogle, S.; Humphrey, D.N.; Patenaude, S.M. (2006) Evaluating the risk to aquatic ecosystems posed by leachate from tire shred fill in roads using toxicity tests, toxicity identification evaluations, and groundwater modeling. Environ. Toxicol. Chem. 25 [2], 400- 411.

17. European Commission (1999) Directive on the Landfill of Waste 1999/31/EC, Journal of European Commission, Brussels, (1999).

18. Almeida Júnior, A.F.; Battistelle, R.A.; Bezerra, B.S.; de Castro, R. (2012) Use of scrap tire rubber in place of SBS in modified asphalt as an environmentally correct alternative for Brazil. J. Cleaner Prod. 33; 236-238. http://dx.doi. org/10.1016/j.jclepro.2012.03.039.

19. Buonanno, A.; Mele, R. (2000) The use of bituminous mix sub-ballast in the Italian State Railways. 2nd Eurasphalt \& Eurobitume Congress, Barcelona, 20-22 September 2000

20. Di Mino, G.; Di Liberto, M.; Maggiore, C.; Noto, S. (2012) A Dynamic Model of Ballasted Rail Track with Bituminous Sub-Ballast Layer. Procedia-Social and Behavioral Sciences 53 [3], 366-378. http://dx.doi.org/10.1016/j. sbspro.2012.09.888.

21. Wang, J.;Zeng X. (2004) Numerical Simulations of Vibration Attenuation of High-Speed Train Foundations with Varied Trackbed Underlayment Materials. J. Vib. Control. 10 [8], 1123-1136. http://dx.doi.org/10.1177/1077546304043268.

22. Wolfe S.L.; Humphrey, D.N.; Wetzel, E.A. (2004) Development of tire shred underlayment to reduce groundborne vibration from LRT track. Geotechnical Engineering for Transportation Projects, Geo-Trans, Los Angeles, 2004

23. Feng, Z.; Sutter, K. (2000) Dynamic properties of granulated rubber/sand mixtures. Geotech. Test. J. 23 [3], 338-344. http://dx.doi.org/10.1520/GTJ11055J. ISSN 0149-6115.

24. Nakhaei, A.; Marandi,S.M.; Sani Kermani, S.; Bagheripour, M.H. (2012) Dynamic properties of granular soils mixed with granulated rubber. Soil Dyn. Earthquake Eng. 43, 124-132. http://dx.doi.org/10.1016/j.soildyn.2012.07.026.

25. Hidalgo, C.; Martínez, P; Medel, E.; Insa, R. (2015) Characterisation of an unbound granular mixture with waste tyre rubber for subballast layers. Mater Struct. 45 [12], 3847-3861. http://dx.doi.org/10.1617/s11527-014-0443-z.

26. Chopra, A.K. (2012) Dynamics of Structures: Theory and Applications to Earthquake Engineering. Prentice Hall, New Jersey, (2012)

27. Manual for Railway Engineering (2015) American Railway Engineering and Maintenance-of-Way Association, AREMA.

28. ASTM D1241 (2007) Standard Specification for Materials for Soil-Aggregate Subbase, Base, and Surface Courses.
American Society for Testing and Materials (ASTM), West Conshohocken, PA.

29. UIC Code 719R (2008) Earthworks and Track-Bed Layers for Railway Lines. International Union of Railways, Paris.

30. PF-7 (2006) General Technical Specifications for Railway Materials PF-7: Sub-ballast. Spanish Ministry of Public Works and Transport, Madrid.

31. ASTM D1557 (2012) Standard Test Methods for Laboratory Compaction Characteristics of Soil Using Modified Effort (56,000 ft-lbf/ft3 (2,700 kN-m/m3)). American Society for Testing and Materials (ASTM), West Conshohocken, PA.

32. UNE 103501 (1994) Geotechnical compaction test. Modified Proctor. Spanish Association for Normalization and Certification (AENOR), Madrid.

33. UNE EN 14146 (2004) Natural stone test methods. Determination of the dynamic modulus of elasticity by measuring the fundamental resonance frequency. Spanish Association for Normalization and Certification (AENOR), Madrid.

34. ASTM D6913 (2009) Standard test methods for particle size distribution (gradation) of soils using sieve analysis. American Society for Testing and Materials (ASTM), West Conshohocken, PA.

35. UNE-EN 933-1 (1998) Tests for geometrical properties of aggregates - Part 1: Determination of particle size distribution - Sieving Method. Spanish Association for Normalization and Certification (AENOR), Madrid.

36. ASTM D7760 (2012) Standard test method for measurement of hydraulic conductivity of tire derived aggregates using a rigid wall Permeameter. American Society for Testing and Materials (ASTM), West Conshohocken, PA.

37. ASTM C127 (2012) Standard test method for density, relative density (specific gravity), and absorption of coarse aggregate. American Society for Testing and Materials (ASTM), West Conshohocken, PA.

38. UNE-EN 1097-3 (1999) Tests for mechanical and physical properties of aggregates. part 3: determination of loose bulk density and voids. Spanish Association for Normalization and Certification (AENOR), Madrid.

39. ASTM D4318 (2010) Standard test methods for liquid limit, plastic limit, and plasticity index of soils. American Society for Testing and Materials (ASTM), West Conshohocken, PA.

40. UNE 103103 (1994) Determination of the liquid limit of a soil by the Casagrande apparatus method. Spanish Association for Normalization and Certification (AENOR), Madrid.

41. UNE 103104 (1993) Test for plastic limit of a soil. Spanish Association for Normalization and Certification (AENOR), Madrid.

42. ASTM C131 (2006) Standard test method for resistance to degradation of small-size coarse aggregate by abrasion and impact in the Los Angeles machine. American Society for Testing and Materials (ASTM), West Conshohocken, PA.

43. UNE-EN 1097-2 (1999) Tests for mechanical and physical properties of aggregates - Part 2: Methods for the determination of resistance to fragmentation. Spanish Association for Normalization and Certification (AENOR), Madrid.

44. ASTM D6928 (2010) Standard test method for resistance of coarse aggregate to degradation by abrasion in the Micro-Deval apparatus. American Society for Testing and Materials (ASTM), West Conshohocken, PA.

45. UNE-EN 1097-1 (1997) Tests for mechanical and physical properties of aggregates - Part 1: Determination of the resistance to wear (micro-Deval). Spanish Association for Normalization and Certification (AENOR), Madrid.

46. ASTM D2974 (2013) Standard test methods for moisture, ash, and organic matter of peat and other organic soils. American Society for Testing and Materials (ASTM), West Conshohocken, PA.

47. UNE 103204 (1993) Organic matter content of a soil by the potassium permanganate method. Spanish Association for Normalization and Certification (AENOR), Madrid. 